\title{
Connetivity Jaringan Public Dengan Satu ISP Menghubungkan Kantor Cabang Dengan Menggunakan Metode Metro Ethernet
}

\author{
Aziz Setyawan Hidayat ${ }^{1)}$, Sobari' ${ }^{2)}$, Baginda Oloan Lubis ${ }^{3)}$, Pas Mahyu Akhirianto ${ }^{4)}$ \\ 1)4)Universitas Bina Sarana Informatika PSDKU Kota Tegal \\ ${ }^{2}$ STMIK Nusa Mandiri Jakarta \\ ${ }^{3}$ Universitas Bina Sarana Informatika Jakarta \\ ${ }^{*}$ Correspondence Author: aziz.aiz@bsi.ac.id, Kota Tegal, Indonesia \\ DOI: https://doi.org/10.37012/jtik.v6i2.288
}

\begin{abstract}
Abstrak
Di zaman sekarang ini komputer merupakan sebuah peralatan yang sangat penting dalam melakukan sistem administrasi dalam sebuah perusahaan dan pertukaran data perusahaan. PT. Tasya Gaya Pesona merupakan perusahaan yang memiliki beberapa cabang yang berada dalam satu kota, yang menggunakan layanan jaringan internet LAN (Local Area Network), sehingga kurang efisien dan perturan data melalui email. Teknologi Metro Ethernet merupakan salah satu perkembangan dari teknologi Ethernet yang dapat menempuh jarak yang luas berskala perkotaan, dengan dilengkapi berbagai fitur yang terdapat pada jaringan Ethernet umumnya. Jaringan Metro Ethernet memberikan layanan dengan menggunakan protokol Ethernet sebagai Metropolitan Area Network (MAN) dengan cara yang sama dengan Local Area Network (LAN) yang menggunakan protokol Ethernet, sehingga jaringan berskala metro dapat dibentuk dengan menggunakan teknologi Ethernet biasa. Metro Ethernet bertindak sebagai jembatan atau bridge dari suatu jaringan menghubungkan wilayah yang terpisah juga menghubungkan LAN dan WAN atau backbone network yang umumnya dimiliki oleh service provider. Pada metropolitan area, perusahaan-perusahaan besar dapat memanfaatkan teknologi Metro Ethernet untuk menghubungkan kantor-kantor cabang mereka ke dalam sistem intranet yang ada di dalam perusahaan tersebut. Dalam transport data, Metro Ethernet menggunakan Multi Protocol Label Switching (MPLS) dan Fiber Optic. Jaringan Metro Ethernet yang saat ini beroperasi di Indonesia menggunakan kabel serat optik dan mempunyai kapasitas $1.000 \mathrm{Mbps}$ atau $1 \mathrm{Gbps}$. Pada penelitian ini akan dibahas mengenai konsep dasar jaringan Metro Ethernet, konfigurasi jaringan Metro Ethernet dan perancangan jaringan Metro Ethernet pada PT. Tasya Gaya Pesona sebagai layanan penghubung jaringan antar cabang.
\end{abstract}

Kata Kunci : Jaringan Komputer, MAN, Metro Ethernet

\begin{abstract}
In this day and age the computer is a very important tool in carrying out administrative systems in a company and exchanging corporate data. PT. Tasya Gaya Pesona is a company that has several branches in one city, which use LAN (Local Area Network) internet services, so it is less efficient and data management via email. Metro Ethernet technology is one of the developments of Ethernet technology that can cover large distances on an urban scale, equipped with various features found in Ethernet networks in general. Metro Ethernet network provides services using the Ethernet protocol as a Metropolitan Area Network (MAN) in the same way as a Local Area Network (LAN) that uses the Ethernet protocol, so that a metro-scale network can be formed using ordinary Ethernet technology. Metro Ethernet acts as a bridge from a network connecting separate areas as well as connecting LANs and WANs or backbone networks which are generally owned by service providers. In metropolitan areas, large companies can take advantage of Metro Ethernet technology to connect their branch offices to the company's existing intranet system. In data transport, Metro Ethernet uses Multi Protocol Label Switching (MPLS) and Fiber Optic. The Metro Ethernet network currently operating in Indonesia uses fiber optic cables and has a capacity of 1,000 Mbps or 1 Gbps. This research will discuss the basic concepts of Metro Ethernet networks, Metro Ethernet network configuration and Metro Ethernet network design at PT. Tasya Gaya Pesona as a network connecting service between branches.
\end{abstract}




\section{PENDAHULUAN}

Di zaman sekarang ini komputer merupakan sebuah peralatan yang sangat penting dalam melakukan sistem admistrasi dalam sebuah perusahaan. Saat ini ternyata masih banyak perusahaan-perusahaan yang mempunyai banyak cabang tetapi masih menggunakan jaringan internet LAN (Local Area Network) yang mempunyai banyak kelemahan. Salah satu kelemahannya adalah kemungkinan password yang dapat ditembus dan virus yang dapat menyebar melalui jaringan, karena sistem transfer data dan komunikasi antara cabang satu dengan cabang yang lainya atau kantor pusat melalui internet, dimana untuk keamanannya sangat rendah, dan sering terjadi gangguan pada layanan ISP (Internet Service Provider) yang tidak bisa dipertanggungjawabkan.

Menurut (Nasir dan Andrianto, 2018) bahwa : "Berdasarkan data dari international Telecommunication Union, menyatakan bahwa terhitung sampai bulan Juli tahun 2017, total pengguna internet di dunia telah mencapai $48 \%$ dari total seluruh penduduk di dunia. Dengan bertambanhnya pengguna internet setiap harinya, maka kebutuhan akan bandwidth pun semakin tinggi”.

PT. Tasya Gaya Pesona merupakan perusahaan yang memiliki cabang usaha menyebabkan pertukaran data harus selalu dilakukan. Pada umumnya pertukaran data adalah transaksi penjualan, laporan penjualan dan laporan fluktuasi omset antara cabang dan kantor pusat dilakukan hanya melalui email maupun tertulis. Pertukaran data yang dilakukan melalui via internet masih memiliki banyak celah keamanan yang tidak dapat dipertanggungjawabkan. Data yang dipertukarkan merupakan data yang sangat sensitif dalam bisnis.

Menurut Yumin dan Shabila (2018:10) menjelaskan bahwa : Metro ethernet adalah salah satu perangkat utama dalam meroutingkan paket-paket informasi, voice data, dan gambar. Keberadaanya sangat menentukan berhasil tidaknya fungsi routing paket-paket informasi yaitu voice, data dan gambar. Alat tersebut yaitu metro ethernet. Metro ethernet yang di gelar salah satunya ALU 7750 SR 12. Pengoperasian ALU 7750 dikarenakan perangkat jaringan tersebut merupakan perangkat yang mampu membawa jumlah trafik dengan kapasitas besar. Sistem keamanan jaringan yang handal dan dapat digunakan sebagai perangkat jaringan utama (Backbone). Keberhasilan pengiriman paket data (throughput) juga ditentukan oleh media transmisi yang digunakan. Media transmisi metro ethernet dapat menggunakan jaringan langsung yaitu direct core optic sebagai penghubung antar node. Sehingga dengan menggunakan router ALU 7750 dan direct core optic maka 
kebutuhan baru disisi pelanggan akan terpenuhi dan mampu melayani layanan triple play dengan baik dan kapasitas dari perangkat existing sebelumnya bisa terpenuhi.

\section{METODE}

Penelitian dilakukan melalui beberapa aktifitas sebagai berikut :

1. Analisa Kebutuhan

Pada tahap awal dilakukan analisa kebutuhan, analisa permasalahan yang muncul, analisa keinginan user akan kestabilan jaringan yang aman dan cepat, dan analisa topologi infrastruktur yang sudah ada pada PT. Tasya Gaya Pesona.

2. Desain

Dari data-data yang didapatkan sebelumnya, tahap desain ini akan membuat gambar desain topologi infrastruktur jaringan Metro Ethernet yang akan dibangun, dan diharapkan dengan gambar ini dapat memberikan pemahaman seutuhnya dari kebutuhan yang ada, yang nantinya akan digunakan untuk penelitian.

3. Testing

Pada tahap ini dilakukan simulasi dengan bantuan tools khusus di bidang virtualisasi sebagai testing atas desain infrastruktur jaringan yang akan dibangun.

4. Implementasi

Pada tahap ini jaringan Metro Ethernet di PT. Tasya Gaya Pesona diimplementasikan. Menurut Yumin dan Shabila (2018:10) menjelaskan bahwa, Metro Ethernet merupakan alat utama dalam penyaluran informasi dari sumber ketujuan. Metro Ethernet existing yang terdiri dari Alcatel Lucent 7750 SR-12.

Perangkat disisi pelanggan yaitu, Customer Equipment (CE) terhubung ke jaringan Metro Ethernet melalui suatu User Network Interface (UNI). Sebagaimana antar muka Ethernet, maka UNI pada jaringan Metro Ethernet dapat berupa:

1. Ethernet memiliki kecepatan data $10 \mathrm{Mbps}$

2. Fast Ethernet memiliki kecepatanakses data $100 \mathrm{Mbps}$

3. Giga Ethernet memiliki kecepatan akses data sebesar $1000 \mathrm{Mbps}$ atau $1 \mathrm{Gbps}$ Layanan dan produk yang dibangkitkan maupun didukung dengan Metro Ethernet dapat disebut sebagai layanan New Wave. Layanan yang diberikan Metro Ethernet ini dapat dikelompokkan dalam fungsi layer 2 dan juga layer 3 IP. Secara generik layanan Metro 
Ethernet dalam layer 2 diantaranya meliputi:

a. E Line (Ethernet Line Point to Point).

Layanan ini memberikan hubungan koneksi point to point, bisa juga disebut Virtual

Leased Line untuk layanan dalam catalog perangkat Metro Ethernet Alcatel .

b. E LAN (Etehernet Local Area Network)

Layanan ini memberikan hubungan satu titik ke beberapa titik yang lain (Point to Multi Point Connection), dalam catalog layanan Alcatel layanan ini disebut juga Virtual Privat LAN (Local Area Network).

Sedangkan fungsi dan layanan Metro Ethernet lainnya dalam layer 3 adalah sebagai berikut:

1. Layanan IP VPN

Layanan ini memberikan koneksi Point / Multipoint to Multipoint yang dalam layanan Alcatel adalah Virtual Privat Network Routed.

2. Circuit Emulation Service (CES)

CES adalah suatu metode untuk membuat suatu sirkuit berbasis TDM diatas suatu IP/MPLS network. Dalam implementasinya fungsi ini bisa menggantikan koneksi E1Trunk antar Node TDM seperti untuk hubungan antar sentral TDM.

3. Layanan Multicast

Layanan Multicast Merupakan layanan komunikasi many to many dalam IP network.

Menurut Ullah (2014:39) menjelaskan bahwa, "Ethernet adalah teknologi komputer berdasarkan pada kerangka jaringan LAN (Local Area Network). Sistem komunikasi melalui Ethernet membagi aliran data ke dalam paket individual yang disebut Frame. Setiap Frame berisi alamat, sumber dan tujuan serta pengecekan error data sehingga data yang rusak dapat dideteksi dan dikirim kembali. Ethernet juga merupakan protokol LAN (Local Area Network) yang memungkinkan setiap personal komputer, berlomba untuk mengakses network. Ethernet merupakan jenis skenario perkabelan dan pemrosesan sinyal untuk data jaringan komputer yang diperkenalkan oleh XEROX pada tahun 1970 dan dikembangkan oleh Robert Matcaffe dan David boggs pada tahun 1972. Ethernet memiliki standar IEEE 802.3. Sebelumnya Ethernet utamanya digunakan dalam teknologi akses, menyediakan akses internet atau interface user ke network. Sampai saat ini kondisi tersebut masih berjalan tetapi standar Ethernet-nya sendiri dikembangkan untuk mampu melayani data pada jaringan transport". 
Fungsi-fungsi layanan pada teknologi Ethernet sebagai jaringan transport merupakan hasil pengembangan terus-menerus. Ethernet mempunyai tiga jenis yang dibedakan berdasarkan kecepatan daya akses datanya yaitu meliputi sebagai barikut:

1. Ethernet memiliki kecepatan akses data $10 \mathrm{Mbps}$

2. Fast Ethernet memiliki kecepatan akses data $100 \mathrm{Mbps}$

3. Gigabit Ethernet memiliki kecepatan akses data sebesar 1000 Mbps atau 1 Gbps Menurut Gartina dalam Fathurrahmad dan Yusuf (2019) Multiprotocol Label Switching (MPLS) adalah teknologi penyampaian paket pada jaringan backbone (jaringan utama) berkecepatan tinggi yang menggabungkan beberapa kelebihan dari sistem komunikasi circuit-switched dan packet-switched yang melahirkan teknologi yang lebih baik dari keduanya. MPLS adalah arsitektur jaringan yang didefinisikan oleh IETF untuk memadukan mekanisme label swapping di layer 2 dengan routing di layer 3 untuk mempercepat pengiriman paket. Paket-paket pada MPLS diteruskan dengan protokol routing seperti OSPF, BGP atau EGP. Protokol routing pada layer 3 sistem OSI, sedangkan MPLS berada diantara layer 2 dan 3.

\section{HASIL DAN PEMBAHASAN}

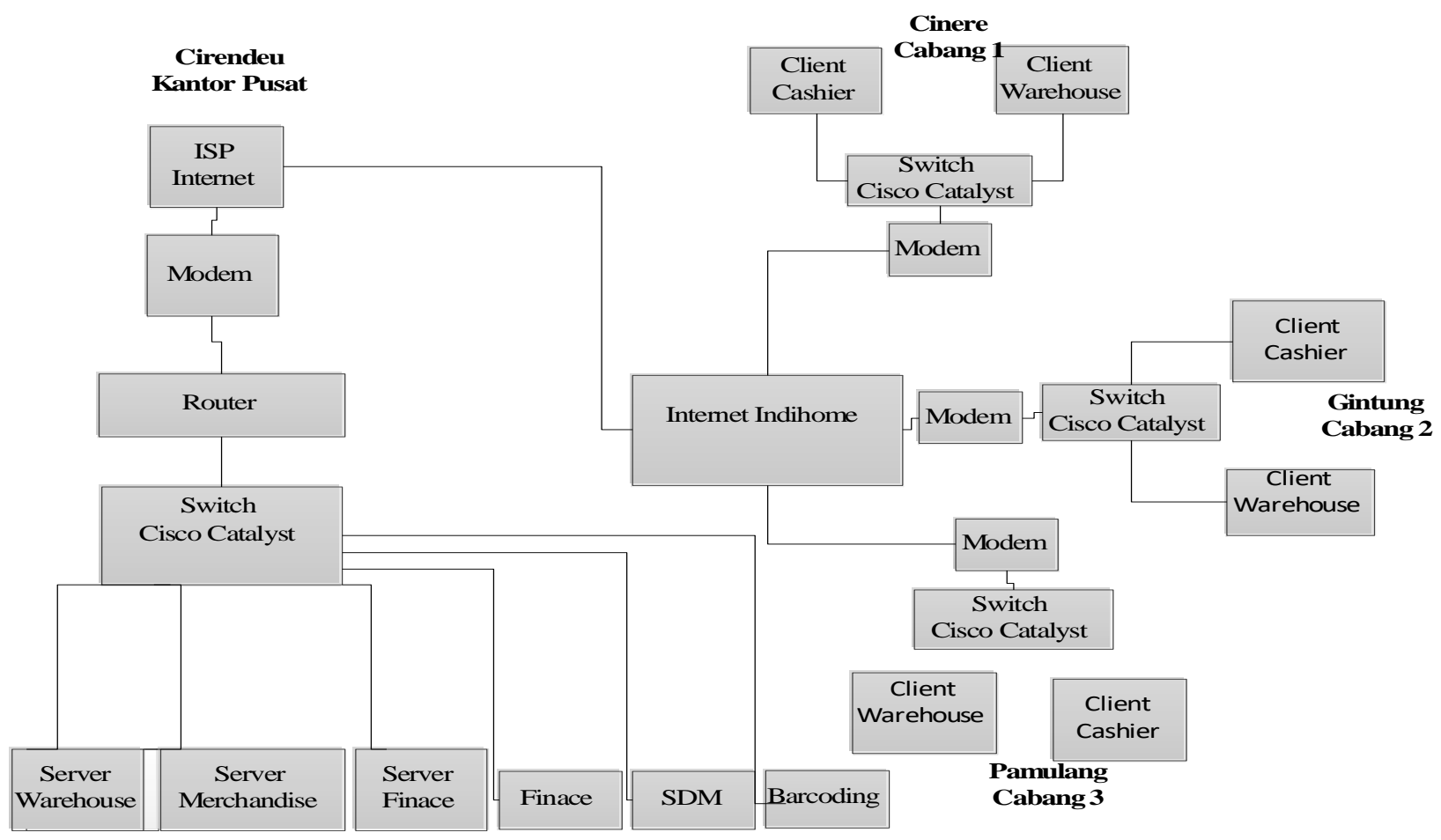

Gambar 1. Topologi Jaringan 
Berdasarkan topologi blok jaringan pada pada objek penelitian terdapat dua kelompok topologi yang digunakan, yaitu :

Topologi jaringan yang digunakan dalam pembahasan penelitian ini adalah topologi bus extended star yang menghubungkan Kantor Pusat dan Kantor Cabang secara keseluruhan. Pada topologi star terdapat pada skema jaringan :

a. Perangkat yang menghubungkan Switch Catalyst dengan perangkat-perangkat Server Warehouse, Server Merchandise, Server Finance, Bagian Finance, Bagian SDM dan Bagian Barcoding. Skema ini terdapat pada Kantor Pusat.

b. Selanjutnya perangkat yang menghubungkan ISP (Indihome) dengan Modem Kantor Pusat, Modem Cabang Pamulang, Modem Cabang Gintung dan Modem Cabang Cinere.

c. Dan yang terakhir adalah Perangkat Switch Catalyst yang menghubungkan Client Warehouse dan Client Cashier, yang terdapat pada kantor-kantor cabang.

Sedangkan untuk topologi bus pada skema jaringan penelitian ini adalah perangkat yang menghubungkan Modem dengan Router dengan Switch Catalyst yang terdapat pada kantor pusat.

Pada pembahasan skema jaringan yang diusulkan untuk jaringan keseluruhan pada penelitian ini, digambarkan dalam bentuk simulasi dengan menggunakan software simulator jaringan komputer. Software yang digunakan adalah Cisco Pakect Tracer. Sebagai gambaran koneksi yang digunakan untuk mengimplementasikan jaringan komputer pada obyek penelitian.

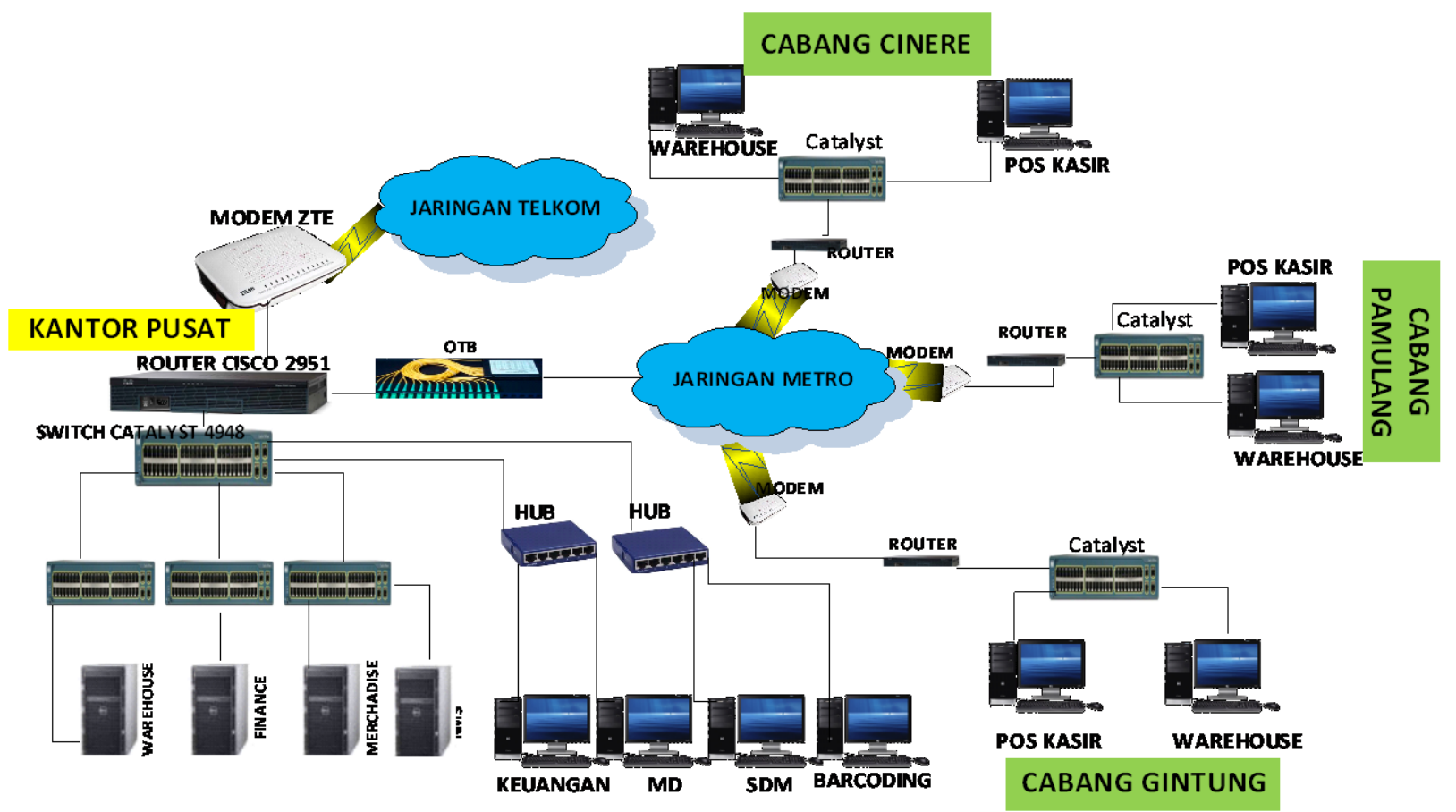

Gambar 2. Skema Jaringan 
Penjelasan mengenai gambar skema di atas adalah sebagai berikut: Pada skema jaringan ini, terdiri dari koneksi modem ke router dan roter ke switch, dihubangkan ke tiga server kemudian dari switch server finance terhubung ke server NMS dan PC user.

Dalam hal ini penulis mengusulkan menggunakan jaringan dengan layanan metro ethernet, dimana layanan Metro mampu menggabungkan beberapa LAN (Local Area Network) dalam wilayah yang mencakup $50 \mathrm{~km}$, sehingga pada cabang dapat mengakses server menggunakan layanan Metro Ethernet, dan tidak lagi menggunakan Internet jaringan public.

Pengujian jaringan adalah untuk mengetahui performansi jaringan internet Indihome dan pengujian jaringan metro. Akan diuji jaringan dari kantor cabang dimana PC cabang masih mengakses komputer menggunakan layanan internet publik dan tidak bisa mengakses ke server kantor pusat. Metode pengujian yang dilakukan yaitu memperlihatkan bahwa jika pengujian ini sudah menggunakan layanan jaringan metro, maka dari kantor cabang sudah menggunakan IP private dan melalui kantor cabang bisa mengakses server kantor pusat. Pengujian dilakukan menggunakan PING dan TRACE dari sisi client ke arah server.

Pada pengujian jaringan awal penulis menggunakan simulasi menggunakan software Cisco Packet Tracer. Berikut ini adalah gambaran simulasi jaringan awal.

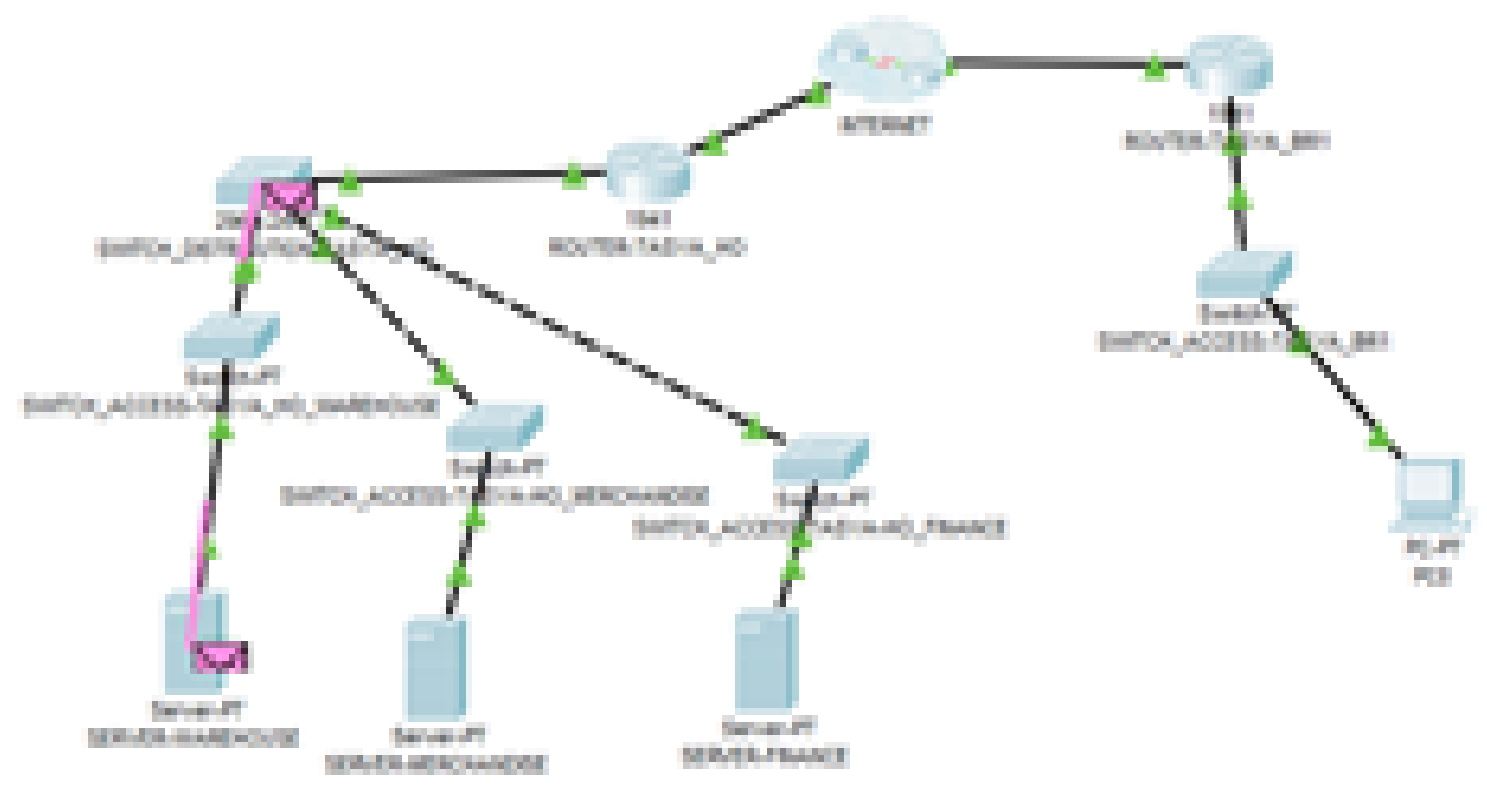

Gambar 3. Simulasi Penelitian

Gambar diatas menunjukan sebuah simulasi menggunakan Cisco Packet Tracer merupakan skema jaringan yang digunakan saat ini. Dimana PC cabang masih mengakses komputer menggunakan layanan internet public. 
Pengujian simulasi menggunakan software Cisco Packet Tracer yang telah menggunakan layanan jaringan metro ethernet adalah sebagai berikut :

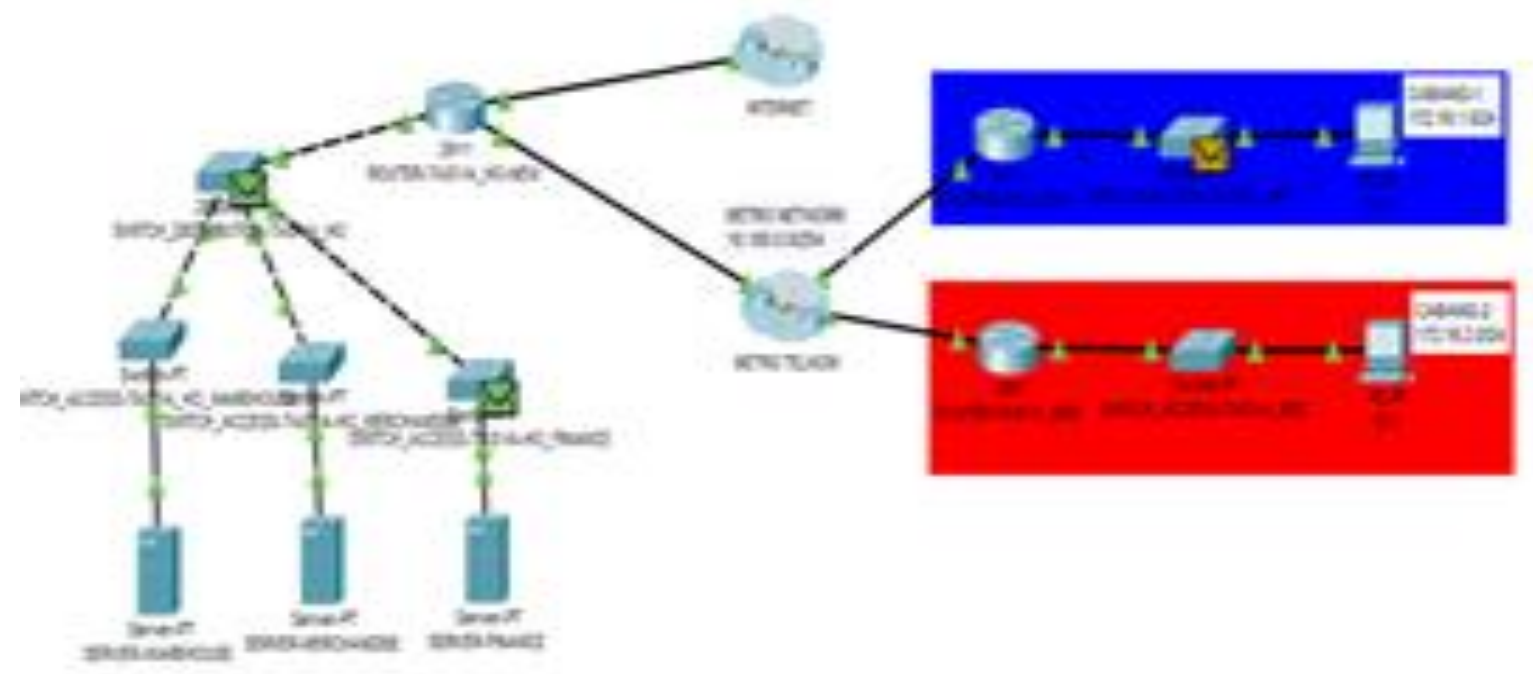

Gambar 4. Skema Jaringan dalam Pengujian

Pada gambar diatas simulasi pengujian jaringan yang telah diterapkan menggunakan kantor pusat, kantor cabang 1 dan kantor cabang 2 telah berjalan.

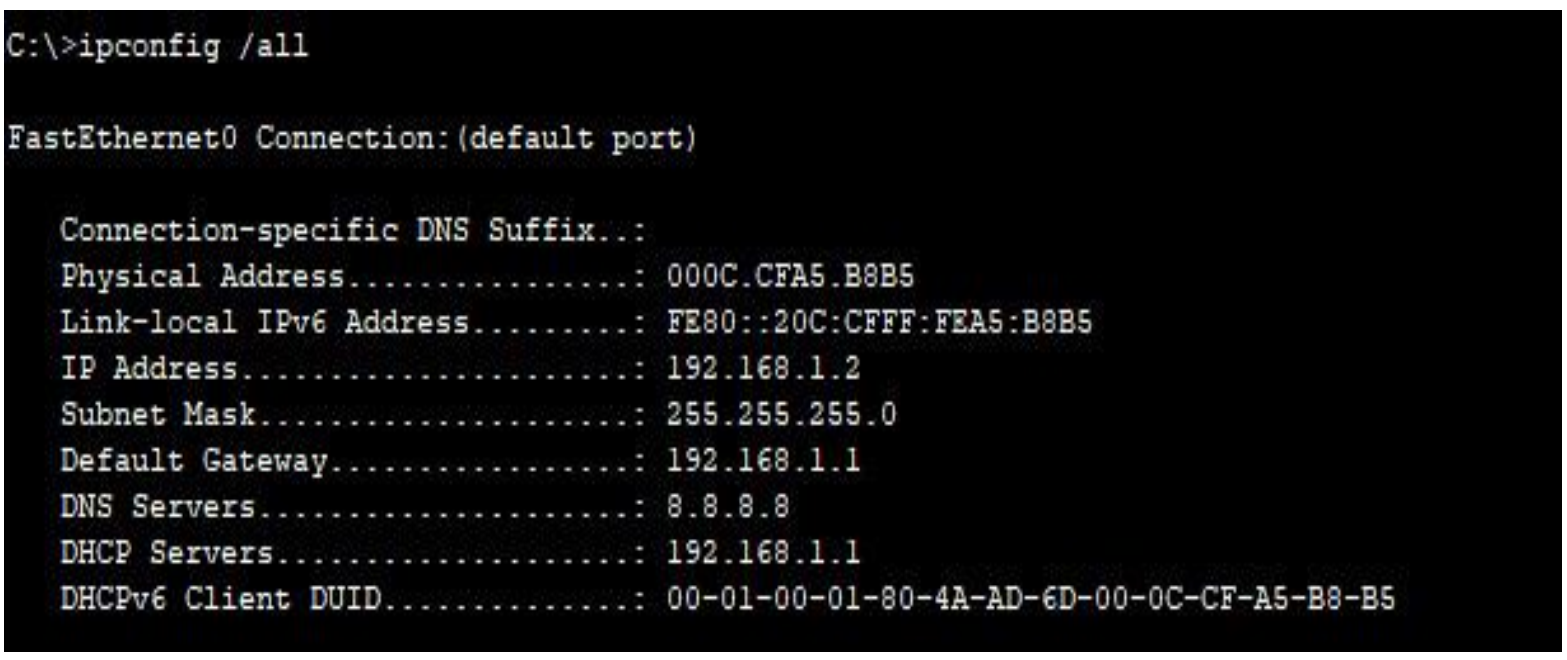

Gambar 5. Address pada Kantor Cabang

Gambar diatas menunjukan IP di cabang 1 berubah, dan cabang 1 dapat mengakses internet via Kantor Pusat.

\section{KESIMPULAN DAN REKOMENDASI}

Dari hasil simulasi menggunakan software Cisco Packet Tracer telah berhasil dan telah terkoneksi didapatkan bahwa jaringan metro ethernet merupakan jaringan yang dapat menggabungkan dari beberapa LAN dengan area kurang lebih $50 \mathrm{~km}$ atau dalam satu kota dan mempunyai tingkat keamanan yang tinggi karena merupakan jaringan private. 
a. Metro Ethernet merupakan jaringan yang luas yang dapat menggabungkan dua LAN (Local Area Network) atau lebih dalam luas wilayah $50 \mathrm{~km}$ secara geografis sehingga tampak seperti satu LAN (Local Area Network).

b. Metro Ethernet merupakan Ethernet sebagai protokol inti yang digunakan untuk menyediakan layanan pada daerah metro dan memungkinkan untuk aplikasi boadband.

c. Jaringan Metro Ethernet merupakan jaringan yang mampu untuk mentransmisikan berbagai macam data secara bersamaan, termasuk data bursty, real time, suara dan video dengan baik melalui media transmisi yang menghubungkan jaringan lokal yang terpisah secara geografis.

d. Metro Ethernet mempunyai tingkat kehandalan tinggi dengan dukungan sitem transmisi Fiber Optic dan network yang handal, beragam protokol aplikasi dan jenis aplikasi dengan penggunaan teknologi clear channel, mempunyai tingkat keamanan yang tinggi karena merupakan jaringan private, jaminan bandwidth karena menggunakan jaringan private, Metro Ethernet juga menyediakan teknologi Ethernet dengan bandwidth $10 \mathrm{Mbps,} 100 \mathrm{Mbps}$, dan 1000Mbps.

e. Metro ethernet merupakan salah satu solusi teknologi untuk High End Market (HEM) dalam memberikan solusi terintegrasi untuk layanan voice, data dan video.

Setelah mempelajari dan menganalisa jaringan LAN ( Local Area Network) yang ada pada

PT. Tasya Gaya Pesona maka rekomendasi yang dapat diberikan adalah sebagai berikut :

a. Direkomendasikan hendaknya untuk segera menggunakan jaringan Metro Ethernet berdasarkan kebutuhan dan permasalahan yang ada saat ini.

b. Direkomendasikan untuk menjaga keamanan dari pihak-pihak yang tidak bertanggung jawab hendaknya untuk dibuat sebuah divisi manajeman yang memonitoring camera cctv dan web server secara 24 jam.

\section{UCAPAN TERIMA KASIH}

Dengan mengucap puji syukur kepada Allah SWT, skripsi ini kupersembahkan untuk:

1. Allah S.W.T yang telah memberikan diri ini kesehatan sehingga penulis menyelesaikan penelitian ini tepat waktu.

2. Kedua Orang tua yang selalu melindungi dalam doa.

3. Bapak Taslan dari PT. Tasya Gaya Pesona atas semua suport dan dukungannya.

4. Semua rekan dosen dan mahassiwa yang telah membantu. 


\section{REFERENSI}

Ahmad Sahroji. (2017). Daftar Negara ASEAN dengan Peringkat Pendidikan Tertinggi.

Retrieved from okezone.com website:

https://news.okezone.com/read/2017/11/24/18/1820178/daftar-negara-asean-denganperingkat-pendidikan-tertinggi

Gorunescu, F. (2011). Data Mining Concepts, Models and Techniques. USA: Springers.

Solikhun, Wahyudi, M., \& Pujiastuti, L. (2019). Jaringan Syaraf Tiruan Memprediksi Penduduk Buta Huruf Menurut Provinsi. In indoms (Ed.), Seminar Nasional Matematika dan Terapan (Vol. 1, pp. 271-278). Pematang Siantar: STMIK Tunas Bangsa. Fathurrahmad dan Yusuf, Salman. 2019. Implementasi Jaringan VPN dengan Routing Protocol terhadap Jaringan Multiprotocol Label Switching (MPLS). E-ISSN : 2580-1643. Jakarta : Jurnal Teknologi dan Informasi Komputer AMIK $\begin{array}{lllll}\text { Indonesia. } & \text { Diambil } & 19 & \text { Januari }\end{array}$ http://journal.lembagakita.org/index.php/jtik/article/view/83/pdf

Harsapranata, Agni Isador. 2014. Implementasi Failover Menggunakan Jaringan VPN dan Metronet pada Astridogroup Indonesia. ISSN: 1978-8282. Vol.8 No.2 - Januari 2015.

Nugroho, Muazam. Achmad, Affandi dan Djoko, Suprajitno Rahardjo. 2014. Rancang Bangun Aplikasi Monitoring Jaringan Menggunakan SNMP (Simple Network Management Protocol) dengan Sistem Peringatan Dini dan Mapping Jaringan. ISSN: 2337-3539.Surabaya: Jurnal Teknik POMITS Vol.3, No.1 2014, Jurusan Teknik Elektro, Fakultas Teknologi Industri, Institut Teknologi sepuluh November (ITS) Surabaya.

Diambil dari:http://download.portalgaruda.org/article.php?article=149260\&val=4186. April 2019)

Nasir, J. \& Andrianto, E (2018). Implementasi Quality Of Service, Limit Bandwidth dan Load Balancing dengan Menggunakan Firmware DD-WRT pada Router Buffalo WHR-HP-G300N. Simetris Jurnal Teknik Mesin, Elektro dan Ilmu Komputer. Diambil dari https://doi.org/10.24176/simet.v9i1.1985.

Rifai, Bakhtiar dan Supriyanto, Eko 2017.Management System Failover Dengan Routing Dinamis Open Shortest Path First Dan Border Gateway Protocol. ISSN : 2527 - 4864 Vol : 3 No. 1 Agustus 2017. Diambil Dari http://ejournal.nusamandiri.ac.id/ejurnal/index.php/jitk/article/view/431(16 April 2019). 
Ullah, Zobair. 2014. Use of Ethernet Technology in Computer Network. Online ISSN: 0975-4172. \& Print ISSN: 0975-4350. Jurnal: Global Journal of Computer Science and Technology Network, Web \& Security.USA. Double Blind Peer Reviewed International Research Journal. Volume 12 Issue 14 Version 1.0 Year 2014. Type: Diambil dari: www.gjcst.org. (18 April 2019).

Yumin, Syamsul El dan Shabila, Luly 2018 Peningkatan Throughput Trunk Metro Ethernet Menggunakan SCF Sebagai Pengganti Jaringan E1 Antar Node. Jurnal Ilmiyah Teknik Elektro, FTI - ISTN Jagakarsa, Jakarta 12640. ISSN : 1410 - 7104 Vol: 28 No. 2 Juli 2018. Diambil dari : https://ejournal.istn.ac.id/index.php/sainstech/article/view/236 (02 April 2019).

Yusof, Mat Ikram. Akmarul, Nizam, Zainudin. Ruhani, Ab Rahman dan Murizah, Kassim. 2015. Services Level Agreement Perfomance Analysis On Quality Of Service UpeMetro Ethernet. ISSN:1819-6608. Malaysia: Faculty Of Electrical Enginering, Universitas Teknologi MARA, UiTM Shah Alam Selangor, Malaysia. Vol.10. No. 2, February 2015. Diambil dari: www.arpnjournal.com. (18 April 2019). 